\title{
Nutritional bioenergetics and estimation of waste production in non-salmonids
}

\author{
Sadasivam J. Kaushik ${ }^{(*)}$ \\ Fish Nutrition Laboratory, Unité mixte Inra-Ifremer, 64310 Saint-Pée-sur-Nivelle, France. \\ Received January 8, 1998; accepted August 27, 1998.
}

\begin{abstract}
The general principles behind the bioenergetic approach for predicting growth, as well as for decreasing feed and nutrient losses, have been set forth for salmonids. Given the diversification of fish farming activities around the world and the ever increasing concern for water quality management, it becomes essential to verify whether an approach developed for salmonids is applicable to other species. Given this general background, an attempt is made here to check the theoretical assumptions and technical considerations behind the bioenergetic principles developed for rainbow trout with other freshwater or marine species. From a conceptual point of view, recent literature data do indicate that as far as nitrogen or energy balance is concerned, the general scheme is as valid for marine species as it is for salmonids, even in quantitative terms. Given the methodological tools available today, it should not be difficult to reduce feed and nutrient losses and to estimate the potential environmental loadings using the same principles for non-salmonids. (C) Ifremer/Elsevier, Paris
\end{abstract}

Nutrition / growth / fresh water fish / marine fish

Résumé - Bioénergétique nutritionnelle et estimation de la production de déchets chez les non-salmonidés. Chez les salmonidés, l'efficacité de l'approche bioénergétique pour prédire la croissance, le taux de rationnement en fonction de la qualité des aliments permettant ainsi de réduire les rejets d'origine nutritionnelle est bien démontrée. Dans le contexte de la diversification de l'aquaculture et pour une plus grande prise en compte des aspects environnementaux, il paraît essentiel de vérifier la validité de telles approches initialement proposées pour les salmonidés, pour d'autres espèces marines ou d'eau douce. Les données actuelles montrent qu'en ce qui concerne les bilans azoté et énergétique, une transposition de ces principes est assez aisée. Les outils méthodologiques et conceptuels existants nous permettent d'envisager une meilleure maîtrise de l'alimentation et une réduction des rejets pour ces espèces comme pour les salmonidés. (C Ifremer/Elsevier, Paris

Nutrition / croissance / poissons d'eau douce / poissons de mer

\section{INTRODUCTION}

The nutritional bioenergetics applicable to salmonids under aquaculture conditions have been dealt with in some detail $[8,21]$. Given that feed wastes contribute in a significant manner to the total nutrient loadings in the aquatic environment and that a precise control and monitoring of voluntary feed intake of fish is difficult to achieve under practical aquaculture conditions, Cho [5] developed these principles further to propose methods for the optimisation of feeding levels for salmonids, especially for rainbow trout. In short, drawing adequate feeding charts and estimation of potential waste output depend upon the precision with which the different parameters are obtained: prediction of growth, estimation of digestible energy (DE) needs, determination of dietary DE levels and the estimation of body gains and consequent losses. Most of the principles developed (see table I) were based on empirical data already available for selected salmonid species. A comprehensive approach along similar lines is lacking for other groups. An attempt is made here to see whether the principles established for salmonids are applicable to other species. Focus is on some of the major marine species of interest to southern Europe, given the rapid development seen over the past decade in the cultivation of species such as European seabass, gilthead seabream and turbot. Compilation and verifi-

* Corresponding author, e-mail: kaushik@st-pee.inra.fr 
Table I. Evaluation of digestihle energy and feed requirements (summarised from [5]).

Evaluate thermal unit growth coefficient (TGC) and predict weight gain

Predict retained energy $(\mathrm{RE})=(W f-W i) \times \% \mathrm{DM} \times \mathrm{kJ}$ per g DM

Maintenance energy needs (HEf, in fasting fish, $\mathrm{kJ} \cdot \mathrm{day}^{-1}$ )

Heat increment of feeding

Non-faecal energy losses

Calculate total DE needs

Determine or calculate dietary $\mathrm{DE}$

Calculate feed required

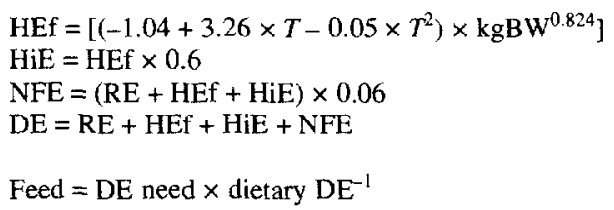

$\mathrm{Wf}=$ final body weight; $\mathrm{Wi}=$ initial body weight; $\mathrm{DM}=$ dry matter; $T=$ temperature in ${ }^{\circ} \mathrm{C} ; \mathrm{BW}=$ body weight; $\mathrm{DE}=$ digestible energy.

cation of such data should allow the development of a working model for estimating growth, feeding levels, nutrient/energy gain and waste output.

\section{OPTIMAL FEEDING LEVELS}

Currently, in order to optimise feeding levels, fish farmers rely on one of three practices: i) apply/adapt feed company charts; ii) predict growth, assume feed efficiency based on farm performance history, and derive specific feeding charts; or iii) apply the nutritional bioenergetic approach consisting of growth prediction, evaluation of DE needs, have accurate data on dietary DE levels and derive feeding charts (table $I$ ).

\section{GROWTH PREDICTION}

Although a number of descriptive parameters are available for a posteriori analysis of growth performance of fish either under experimental or under practical culture conditions, reliable predictive models of growth are rare. First, it has to be recognised that, in poikilotherms, there is a definite relationship between water temperature and consequent trophic activity and growth. Second, the specific growth rates (SGRs) decline with increasing body weight in almost all animals. Third, there exists a clear relationship between length and body weight.

Based on the above and on the original observations of Iwama and Tautz [16], Cho [5] found that growth prediction using an index called daily growth coefficient (DGC) based on the differences of body weights raised to one-third power was more reliable than conventional descriptors such as specific growth rate (SGR) based on the differences between logarithmic transformation of body weights. Muller-Feuga [28] also reported that an exponent of about $1 / 3$ was the most suited for some finfish species. It is noteworthy that this growth model (although differently termed as 'GF3' or 'GC3' instead of adopting the original terminology of DGC or TGC [5]) is already being proposed as a 'new' measure for growth of salmonids by some commercial feed manufacturers.

One major advantage of this DGC is that at a given temperature, it is very much independent of body weight. In order to check the validity of this predictor under practical conditions, data from a number of trout farms were collected and the two growth descriptors plotted against body weight. As can be seen from figure 1, while SGRs decrease with increasing body weights, the DGC values remain more or less stable in rainbow trout. Such observations have also been made with common carp [19]. Using data from some marine species, we have also found that such a general principle is also applicable to these species (figure 2).

Based on the above and in order to take into account variations in water temperature, a thermal unit growth coefficient (TGC) calculated as

$$
\mathrm{TGC}=\left(W f^{1 / 3}-W_{i}^{1 / 3}\right) / \text { sum degree days }
$$

where $W f$ and $W i$ are the final and initial body weight, respectively, has been proposed [5]. Theoretically, this should be relatively stable for a given genotype, feed quality, and feeding and husbandry practices. Once we have this information based on past farm records for a species and genotype, prediction of weight gain over a given period should be possible using the following:

Final body weight $=\left[W i^{1 / 3}+(\text { sum degree days } \times \text { TGC })\right]^{3}$

Some values for the TGC of different salmonids have been previously provided [5]. It has also been made explicit that the TGC values would vary depending upon species, stock, nutrition, husbandry and other factors, and that it is necessary to calculate specific TGC for spccific aquaculture systems using past growth records [5]. Based on information available from the literature and from our own experimental data, data on the TGC for salmonids as well as non-salmonids are provided in table $I I$. In drawing this table, only data with best growth rates under a given set of environmental and culture conditions were retained. Thus, these values should be considered as providing average values under normal culture conditions.

One major assumption when using TGC is that it is a constant figure for a given species and genotype and that growth is linearly related to water temperature. In fact, this is applicable only within the normal temperature range of the species. Thus, for rainbow trout, our own data led to a slight adjustment of this TGC, apparently affected by water temperature (see table II). Such information for other species is lacking. Recent studies by Burel et al. [2] show clearly that growth rate of tur- 
Figure 1. Relationship between body weight (BW) and two growth descriptors $(S G R=$ specific growth rate; $D G C=$ daily growth coefficient) in the rainbow trout under fish farm conditions.

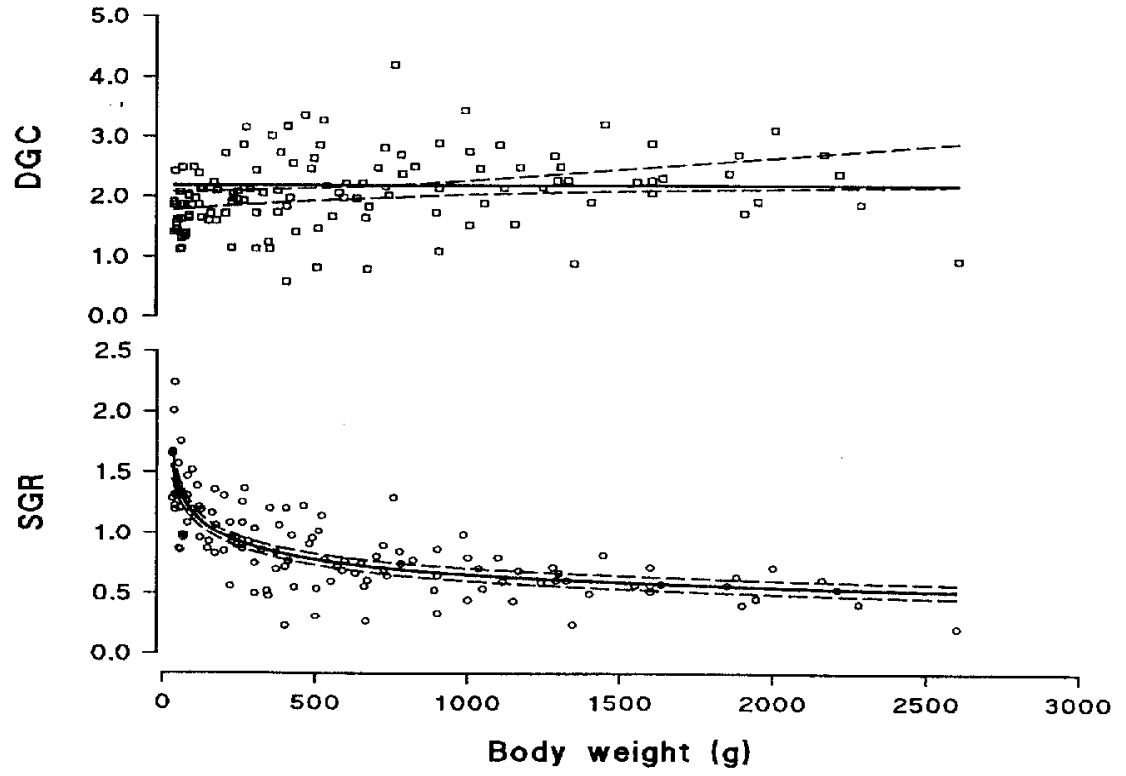

bot increases when increasing temperature from 8 to $17^{\circ} \mathrm{C}$ but is reduced when the water temperature is further raised to $20^{\circ} \mathrm{C}$.

\section{MAINTENANCE ENERGY NEEDS}

The maintenance energy needs (HEf) are known to be related to both body weight and temperature in fish. Based on direct calorimetry (using a modified adiabatic bomb calorimeter to measure small increments of heat), Smith et al. [34] concluded that the effect of size on metabolic rate was linear from 1 to $4 \mathrm{~g}$ and proportional to $\mathrm{W}^{-0.63}$ for larger fish ( 4 to $57 \mathrm{~g}$ ). Further, they found that heat production changed linearly with temperature over the range $\left(3\right.$ to $\left.18^{\circ} \mathrm{C}\right)$ tested. Their values however appear to be considerably overestimated [7]. A more precise estimation of the daily maintenance energy needs of rainbow trout, expressed as $\mathrm{kJ} \cdot$ day $^{-1}$, has been proposed [8]:

$$
\left(-1.04+3.26 \times T-0.05 \times T^{2}\right) \times \mathrm{kg} \text { body weight }{ }^{0.824}
$$

where $T$ is the temperature $\left({ }^{\circ} \mathrm{C}\right)$.

The above equation implies that the maintenance energy need is related to metabolic body weight and that it would increase with increasing temperature up to a certain level and would decline when the temperature goes beyond this level. In the case of salmonids, such a standard environmental temperature has been rather arbitrarily set at $15^{\circ} \mathrm{C}$. Such a relationship also exists in marine fish such as turbot $[2,37]$, seabream or seabass [31].

Generally, measurement of metabolic rates and energy requirements in aquatic animals are made using indirect methods wherein heat production estimates are based on oxygen uptake. Generally, the HEf is assumed to be equivalent to the basal metabolic rates measured under short (4 to 7 days) unfed conditions. Other assumptions involve the conversion of oxygen uptake to its energy equivalents $\left(1 \mathrm{~g} \mathrm{O}_{2}=13.6 \mathrm{~kJ}\right)$. In the rainbow trout, an average value of $3.5-4 \mathrm{~g} \mathrm{O}_{2} \cdot \mathrm{kg}^{-1}$ -day ${ }^{-1}$ has been reported $[8,21]$. In the case of marine species, data obtained under controlled conditions are limited. Morales and Oliva-Teles [27] found that the daily average oxygen consumption of unfed European seabass ranged between 3.9 and $4.8 \mathrm{~g} \mathrm{O}_{2} \cdot \mathrm{kg}^{-1} \cdot \mathrm{day}^{-1}$. In the seabream, the data are slightly contradictory: while the data of Guinea and Fernandez [15] suggest values of around 2.4 $3 \mathrm{~g} \mathrm{O}_{2} \cdot \mathrm{kg}^{-1} \cdot \mathrm{day}^{-1}$, data of Requena et al. [31] indicate daily minimum oxygen uptake values above $5 \mathrm{~g} \mathrm{O}_{2} \cdot \mathrm{kg}^{-1} \cdot \mathrm{day}^{-1}$. In turbot, values of 2.4 $3.0 \mathrm{~g} \mathrm{O}_{2} \cdot \mathrm{kg}^{-1} \cdot$ day $^{-1}$ have been recorded [29], comparable to those found with seabass. Sanchez et al. [33] proposed some descriptive relationships between body weight, temperature and oxygen uptake in turbot. Recalculation of their data show the body weight exponent to be about 0.75 .

\section{HEAT INCREMENT OF FEEDING}

From studies with rainbow trout $[5,7,8]$, the heat increment of feeding ( $\mathrm{HiE}$ ) has been found to be equivalent to about $60 \%$ of the maintenance energy needs. With regard to marine fish, comparable quantitative data are also limited. In European seabass, recalculation of recent data shows that the $\mathrm{HiE}$ is about $40 \%$ of the maintenance needs $(\mathrm{HiE}=\mathrm{HEf} \times 0.4)$. In the gilthead seabream, similar calculations based on data of Guinea and Fernandez [15] lead to comparable figures of HEf $\times 0.4(13-30 \% \mathrm{GE})$. Data for turbot [29] are also very much comparable $(\mathrm{HEf} \times 0.4)$. 

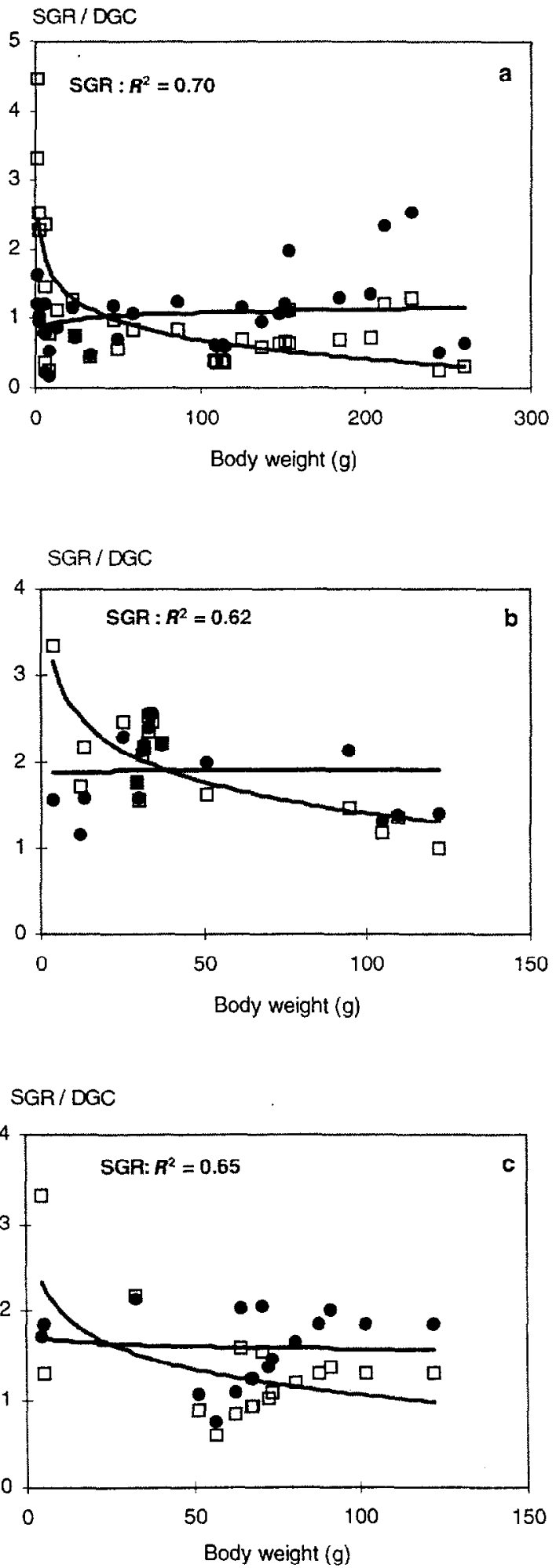

Figure 2. Relationship between body weight (BW) and two growth descriptors (SGR $=$ specific growth rate $(0)$; DGC $=$ daily growth coefficient $(\square)$ ) in (a) seabass, (b) seabream and (c) turbot. Based on data from personal experimental work as well as from the literature.
However, studies with farm animals suggest that $\mathrm{HiE}$ is independent of $\mathrm{HEf}$ and is probably more linked to protein or fat deposition rates. Available data with rainbow trout indicate that the heat increment of feeding is related to digestible nitrogen intake, equalling about $27-30 \mathrm{~kJ}$ per gram digestible nitrogen intake [8]. Data from common carp [3] or tilapia [23] suggest much higher figures than those found for rainbow trout. In the European seabass, much lower values in the range 13-15 $\mathrm{kJ}$ per gram digestible nitrogen intake are found. Although in most species there seems to be a relationship between nitrogen intake and $\mathrm{HiE}$, further insight on the relationship between heat increment of feeding and protein deposition as possibly affected by overall growth rate is required.

\section{FAECAL ENERGY LOSSES}

Although non-faecal nitrogen losses contribute significantly to environmental load in terms of ammonia nitrogen [20], from the point of view of energy balance, their contribution (3-6\% of digestible energy) is relatively small $[8,21]$. In the rainbow trout, endogenous (branchial and urinary) nitrogen excretion (ENE) rates measured in fish after 3-4 days of fasting have been found to vary between 80 and $130 \mathrm{mg} \mathrm{N} \cdot \mathrm{kg}^{-1} \cdot \mathrm{day}^{-1}$, affected most by water temperature and body weight $[17,18]$. Some recent studies on Atlantic salmon [13] suggest that the values might be much lower. With regard to marine fish, data of Ballestrazzi et al. [1] and of Dosdat et al. [12] also show that the ENE rates in European seabass, gilthead seabream or turbot would be in the range 100 to $160 \mathrm{mg} \mathrm{N} \cdot \mathrm{kg}^{-1} \cdot \mathrm{day}^{-1}$, which is comparable to values found for rainbow trout.

Under fed conditions, it has been demonstrated in several freshwater or marine species that the total nitrogen excretion increases with increasing $\mathrm{N}$ intake $[2,4,13,17,23]$. Such a linear relationship however has to be considered in the light of possible effects of the dietary DE levels since ammonia $\mathrm{N}$ excretion is very much influenced by the dietary $\mathrm{DP}$ to $\mathrm{DE}$ ratios $[20,22]$. Studies with rainbow trout [25] have shown that the regression slopes between nitrogen intake and nitrogen excretion as well as the basal nitrogen excretion levels are affected by the dietary digestible protein to digestible energy (DP/DE) ratios. At a dietary DP/ DE ratio of $18 \mathrm{mg} \cdot \mathrm{kJ}^{-1}$, the relationship between nitrogen excretion $(\mathrm{Ne})$ and nitrogen intake (NI) was $75.1+0.307 \times \mathrm{NI}$ and at a higher DP/DE ratio of $23 \mathrm{mg} \cdot \mathrm{kJ}^{-1}$, the relationship was $84.9+0.343 \times \mathrm{NI}$ [25]. With regard to marine species, one should admit that there is a relative lack of quantitative data on $\mathrm{N}$ excretion rates as affected by dietary DP/DE levels. Available data [1] however indicate that as with salmonids, $\mathrm{N}$ excretion is reduced with decreasing DP/DE ratios in species such as seabass. Indirect evidence of this effect has also been shown in other studies conducted with seabass [11] and seabream (Médale, pers. comm.). Awaiting more quantitative data for all the 
Table II. Range of values for the thermal growth coefficient (TGC) calculated for different species of finfish (based on literature data as well as on experimental data from our own laboratory). These values will have to be adjusted to the specific genotype, environmental and husbandry conditions.

\begin{tabular}{lcc}
\hline Species & Range & Average \\
\hline Rainbow trout & $15.210^{-4}-17.310^{-4}$ & $0.00297-9.710^{-4} \times T$ \\
Brown trout & $13.310^{-4}-15.510^{-4}$ & $14.410^{-4}$ \\
Atlantic salmon & $16.010^{-4}-20.210^{-4}$ & $19.510^{-4}$ \\
Coho salmon & $15.710^{-4}-24.110^{-4}$ & $21.010^{-4}$ \\
Common carp & $9.510^{-4}-15.710^{-4}$ & $14.010^{-4}$ \\
Tilapia & $10.110^{-4}-1410^{-4}$ & $12.810^{-4}$ \\
European catfish & $6.010^{-4}-21.510^{-4}$ & $20.010^{-4}$ \\
European seabass & $5.610^{-4}-8.610^{-4}$ & $6.6710^{-4} \pm 1.2010^{-4}$ \\
Gilthead seabream & $6.610^{-4}-10.010^{-4}$ & $8.6910^{-4} \pm 1.9010^{-4}$ \\
Turbot & $6.810^{-4}-11.910^{-4}$ & $9.9010^{-4} \pm 1.4010^{-4}$ \\
\hline
\end{tabular}

species of interest, an estimate for these branchial and urinary losses as equivalent to ( $\mathrm{RE}+\mathrm{HEf}+\mathrm{HiE})$ $\times 0.06$, as proposed for salmonids [5], should he applicable without a great degree of error.

\section{NUTRIENT AND ENERGY GAIN}

While the protein or ash content of the whole body appears to vary little with growth of a given species of fish, whole body energy content varies considerably over time. Whole body gross energy content increases, mainly due to increased fat deposition, with increasing age or size in almost all species of fish, as in most terrestrial vertebrates. However, the degree of such fat deposition is also very dependent on nutritional history. Seasonal changes in body composition, in relation to specific physiological stages or endocrine status, are also known to occur. That there are considerable interspecific differences in fat deposition and lissue distribution is also recognised. In salmonids, genotype differences in fat content have also been reported [14]. So far, such genetic differences have not been found in less domesticated marine species.

Given the above, prediction of nutrient energy gain as $\mathrm{RE}=(W f-W i) \times \%$ dry matter $\times \mathrm{kJ} \cdot \mathrm{g}$ dry matter $^{-1}$ [5] should be made for different growth stages over the life cycle, since both dry matter and the energy content increase with increasing body size. A reliable database on temporal changes in body composition for a given genotype, taking into account the effects of past nutrition, is urgently needed for all aquaculture species.

\section{NUTRIENT AVAILABILITY AND DIGESTIBLE ENERGY}

To meet all the above energy requirements through dietary supply, it is also indispensable to have reliable data on the digestible energy (DE) content of the diets being used. While some such reliable data are available for the rainbow trout, information for other species is fragmentary. The best way to obtain such information is to use approved standardised methodology. Reliable faecal collection methods developed for the rainbow trout $[9,10]$ can successfully be used with marine spe- cies. Efforts should be made to provide quantitative data for all possible ingredients and for the species involved. Available data [35] suggest that for most practical ingredients, the digestibility values for protein are comparable between species, differences being more apparent with regard to carbohydrate sources. In the absence of measured DE values, one can still have a near approximation using the following values for each macronutrient: crude protein $\times 0.9 \times 0.236 \mathrm{~kJ}$; crude fat $\times 0.95 \times 0.35 \mathrm{~kJ}$; and carbohydrates $\times 0.5$ (or $0.7-0.8) \times 0.17 \mathrm{~kJ}$.

Although the potential effects of excess phosphorus supply on water quality are well recognised, knowledge on P flux is limited. Availability of phosphorus from dietary sources appears to differ significantly between species [24]. Very few studies have dealt with the quantification of dissolved phosphorus losses in fish under controlled conditions [1, 26]. Dietary phytase supplementation has also been found to improve phosphorus availability both in freshwater [32] and marine fish [30], providing increased opportunities for the use of plant ingredients in fish diets. Besides, there are indications that absorption of phosphorus from the surrounding water is not negligible in the case of marine fish.

\section{ESTIMATION AND REDUCTION OF NUTRIENT LOSSES}

In the context of aquaculture, release of suspended matter, nitrogen and phosphorus can be significantly reduced through precise knowledge on requirement, supply and retention. Once there are some reliable data on the nutrient and energy requirements of fish for a given production performance, together with data on the DE contents of the diet, it is possible to draw feeding charts for a given species. In the case of salmonids, application of the above principles has led to the development of working models and even a complete software [6]. From what has been presented in previous sections, it appears clear that such an approach can be advantageously applied also to other marine species.

Based on these, worksheets corresponding to several non-salmonids have been developed to obtain minimal 
Table III. Theoretical estimations of weight gain, feed efficiency (gain/dry matter intake) and potential environmental load in terms of suspended matter (SM), nitrogen (N) and phosphorus $(\mathrm{P})$ in seabass and seabream of $100 \mathrm{~g}$ initial body weight, grown at two temperatures and with two different diets over a duration of 16 weeks.

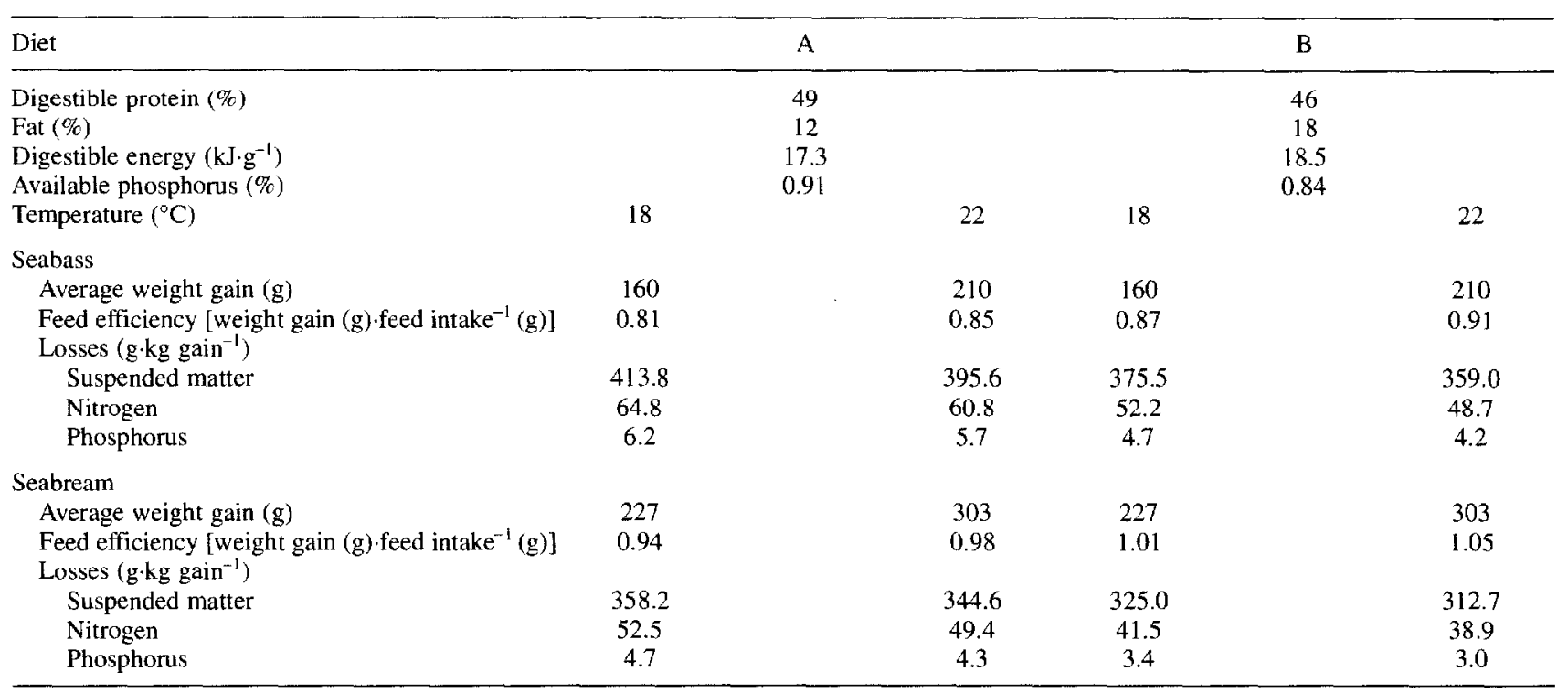

predictive estimates of nutrient losses. A theoretical estimation of growth as well as of waste production by seabass and seabream fed two different diets and grown at two temperatures is presented in table III. It can be secn from this that an increase in DE levels with a concomitant decrease in DP as well as in available P content can significantly reduce waste production. The theoretical bases developed for salmonids appear thus to be also applicable to these marine species. Experimental evidence of such a possible decrease in wastes through adequate nutritional practices is now also available [11].

Extensive knowledge on the total energy as well as nutrient needs per unit growth of all such novel species is required. Besides, as proposed earlier [36], notwithstanding the developments of feeding charts based on bioenergetic principles, reduction of feed wastes, a major source of suspended matter in aquaculture, needs more attention and should incorporate behavioural aspects.

\section{CONCLUSION}

As mentioned above, the methodological tools available today enable us to reduce feed and nutrient losses and to estimate the potential environmental loadings from marine aquaculture using the same principles that have been developed for salmonids. However, the lack of basic quantitative data on the nutrient and energy requirements might make such predictions less reliable than they are for salmonids, and further experimental work is needed for at least some aspects. Besides, given the quantitative importance of semi-intensive systems in the global aquaculture production, a fuller understanding of nutrient flow under variably confined conditions of pond culture is another crucial point for environmentally sustainable development of aquatic animal production. The preeminence of the nutritional approach to reduce waste production at the source holds particular significance under conditions where clear impact assessments can not generally be easily made.

\section{REFERENCES}

[1] Ballestrazzi R., Lanari D., D'Agaro E., Mion A., The effect of dietary protein level and source on growth, body composition, total ammonia and reactive phosphate excretion of growing sea bass (Dicentrarchus labrax), Aquaculture 127 (1994) 197-206.

[2] Burel C., Person-Le Ruyet J., Gaumet F., Le Roux A., Sévère A., Bouf G., Effects of temperature on growth and metabolism in juvenile turbot, J. Fish Biol. 49 (1996) 678-692.
[3] Chakraborty S.C., Ross L.G., Ross B., Specific dynamic action and feeding metabolism in common carp, Cyprinus carpio L., Comp. Biochem. Physiol. 103A (1992) 809-815.

[4] Chakraborty S.C., Ross L.G., Ross B., The effect of dietary protein level and ration level on excretion of ammonia in common carp Cyprinus carpio, Comp. Biochem. Physiol. 103A (1992) 801-808.

[5] Cho C.Y., Feeding systems for rainbow trout and other salmonids with reference to current estimates of energy and protein requirements, Aquaculture 100 (1992) 107123. 
[6] Cho C.Y., Bioenergetics in the formulation of highnutrient-dense (HND) diets, feeding standards and waste reduction for salmonid aquaculture, Proc. Canadian Feed Industry Assoc. Eastern Nutrition Conf. Halifax, Nova Scotia, Canada, 1996, pp. 239-246.

[7] Cho C.Y., Bureau D.P., Determination of the energy requirements of fish with particular reference to salmonids, J. Appl. Ichthyol. 11 (1995) 141-163.

[8] Cho C.Y., Kaushik S.J., Nutritional energetics in fish. Protein and energy utilization in rainbow trout, in: Bourne J.H. (Ed.), Aspects of Food Production, Consumption and Energy Values, World Rev. Anim. Nutr. 61, 1990, pp. 132-172.

[9] Cho C.Y., Slinger S.J., Bayley H.S., Bioenergetics of salmonid fishes: energy intake, expenditure and productivity, Comp. Biuchen. Physiol. 73B (1982) 25-41.

[10] Choubert G., De La Noüe J., Luquet P., Digestibility in fish: improved device for the automatic collection of faeces, Aquaculture 29 (1982) 185-189.

[11] Dias J., Alvarez M.J., Diez A., Arzel J., Corraze G., Bautista J.M., Kaushik S.J., Regulation of hepatic lipogenesis by dietary protein / energy in juvenile European seabass (Dicentrarchus labrax), Aquaculture 161 (1998) 169-186.

[12] Dosdat A., Servais F., Métailler R., Huelvan C., Desbruyères $E$., Comparison of nitrogenous losses in five teleost fish species, Aquaculture 141 (1996) 107-127.

[13] Forsberg O.I., The impact of varying feeding regimes on oxygen consumption and excretion of carbon dioxide and nitrogen in post-smolt Atlantic salmon Salmo salar L., Aquac. Res. 28 (1997) 29-41.

[14] Gjedrem T., Flesh quality improvement in fish through breeding, Aquac. Int. 5 (1997) 197-206.

[15] Guinea J., Fernandez F., Effect of feeding frequency, feeding level and temperature on energy metabolism in Sparus aurata, Aquaculture 148 (1997) 125-142.

[16] Iwama G.K., Tautz A.F., A simple growth model for salmonids in hatcheries, Can. J. Fish. Aquat. Sci. 38 (1981) 649-656.

[17] Kaushik S.J., Influence of the nutritional status on the daily patterns of nitrogen excretion in carp (Cyprinus carpio L.) and rainbow trout (Salmo gairdneri R.), Reprod. Nutr. Develop. 20 (1980) 1751-1765.

[18] Kaushik S.J., Influence of a rise in temperature on the nitrogen excretion of rainbow trout (Salmo gairdneri R.), in: Tiews K. (Ed.), Aquaculture in Heated Effluents and Recirculated Systems, Heenemann GmbH, Berlin, vol. I, 1980, pp. 77-89.

[19] Kaushik S.J., Nutrient requirements, supply and utilization in the context of carp culture, Aquaculture 129 (1995) 225-241.

[20] Kaushik S.J., Cowey C.B., Ammoniogenesis and dietary factors affecting nitrogen excretion, in: Cowey C.B., Cho C.Y. (Eds.), Nutritional Strategies and Aquaculture Waste, Univ. Guelph, Guelph, Canada, 1991, pp. 3-19.

[21] Kaushik S.J., Médale F., Energy requirements, utilization and supply to salmonids, Aquaculture 124 (1994) 81-97.

[22] Kaushik S.J., Oliva-Teles A., Effect of digestible energy on nitrogen and energy halance in rainbow trout, Aquaculture 50 (1986) 89-101.
[231 Kaushik S.J., Doudet T., Médale F., Aguirre P., Blanc D., Protein and energy needs for maintenance and growth of Nile Tilapia (Oreochromis niloticus) using different criteria, J. Appl. Ichthyol. 11 (1995) 290-296.

[24] Lall S.P., Digestibility, metabolism and excretion of dietary phosphorus in fish, in: Cowey C.B., Cho C..Y. (Eds.), Nutritional Strategies and Aquaculture Waste, Univ. Guelph, Guelph, Canada, 1991, pp. 21-36.

[25] Médale F., Brauge C., Vallée F., Kaushik S.J., Effects of dietary protein/energy ratio, ration size, dietary energy source and water temperature on nitrogen excretion in rainbow trout, Wat. Sci. Tech. 31 (1995) 185-194.

[26] Médale F., Boujard T., Vallée F., Blanc $M$. Mambrini M., Roem A., Kaushik S.J., Voluntary feed intake, nitrogen and phosphorus losses in rainbow trout (Oncorhynchus mykiss) fed increasing dictary levels of soy protein concentrate, Aquat. Living Resour. 11 (1998) 239-246.

[27] Morales A.E., Oliva-Teles A., Resultados preliminares sobre la utilizacion metabolica de dietas con dos niveles lipidicos en lubina (Dicentrarchus labrax), in: CastelloOrvay F., Calderer A., Reig L. (Eds.), Proc. V Natl Congress on Aquaculture, Univ. Barcelona, 1995, pp. 570 575.

[28] Muller-Feuga A., Modélisation de la croissance des poissons d'élevage, Rapp. Sci. Tech. Ifremer, Plouzané, France, $n^{\circ} 21,1990,57 \mathrm{p}$.

[29] Oliva-Teles A., Henriques M.C., Kaushik S.J., The effect of dietary protein level on energy metabolism of turbot (Scophthalmus maximus), in: Castello-Orvay F., Calderer A., Reig L. (Eds.), Proc. V Natl Congress on Aquaculture, Univ. Barcelona, 1995, pp. 576-581.

[30] Oliva-Teles A., Pereira J.P., Gouveia A., Gomes E.F., Utilisation of diets supplemented with microbial phytase by seabass (Dicentrarchus labrax), Aquat. Living Resour. 11 (1998) 255-259.

[31] Requeña A., Fernandez-Borras J., Planas J., The effects of a temperature rise on oxygen consumption and energy budget in gilthead sea bream, Aquac. Int. 5 (1997) 415-426.

[32] Rodehutscord M., Becker A., Pfeffer E., Effect of a supplemental Aspergillus niger phytase on the utilization of plant phosphorus by rainbow trout (Oncorhynchus mykiss), Arch. Tierernahr. 48 (1995) 211-219.

[33] Sanchez F.J., Cal R.M., Guisande C., Oxygen consumption of turbot Scophthalmus maximus juveniles between $15^{\circ} \mathrm{C}$ and $22^{\circ} \mathrm{C}$, under experimental conditions, Proc. World Aquaculture Society Meeting, Torremolinos, Spain, 1993, p. 459.

[34] Smith R.R., Rumsey G.L., Scott M.L., Net energy maintenance requirements of salmonids as measured by direct calorimetry. Effect of body size and environmental temperature, J. Nutr. 108 (1978) 1017-1024.

[35] Spyridakis P., Métailler R., Gabaudan J., Riaza A., Studies on nutrient digestibility in European seabass (Dicentrarchus labrax). 1. Methodological aspects concerning faeces collection, Aquaculture 77 (1989) 61-70.

[36] Thorpe J.A., Cho C.Y., Minimising waste through bioenergetically and behaviourally based feeding strategies, Wat. Sci. Tech. 31 (1995) 29-40.

[37] Waller U., Factors influencing routine oxygen consumption in turbot, Scophthalmus maximus, J. Appl. Ichthyol. 8 (1992) 62-71. 